\title{
Rethinking the China-US Balance of Trade: 1990-2005
}

\author{
Xiaoping Xu
}

Department of International Trade, School of Economics, Huazhong University of Science \& Technology, Wuhan, China. Email: jackxu@mail.hust.edu.cn

Received December $23^{\text {rd }}$, 2011; revised January $28^{\text {th }}$, 2012; accepted February $14^{\text {th }}, 2012$

\begin{abstract}
Since 1993, American trade deficit with China is expanding and the gap is becoming increasingly bigger. The widening bilateral trade imbalance has caused growing concerns. This paper, by using empirical method and adjusting the data of trade from 1989 to 2005, finds that the causes of the imbalance of China-US trade are as follows: 1) the imbalance of domestic demands of US; 2) the adjustment of American economic structure and 3) the growing of multinational enterprises. The paper also finds that the imbalance of China-US trade is not as big as it was reported by US; the imbalance of China-US trade is an inevitable result of economic development, and the trade deficit does not necessarily mean a loss of profit. In fact, American investors and consumers have greatly benefited from China-US trade.
\end{abstract}

Keywords: China-US Trade Imbalance; Adjustment; Conversion; HK Transit Trade; Economic Factors

\section{Introduction}

Since China's government adopted economic reforms and opening policy to the outside world in 1978, the bilateral trade between China and US has been developed rapidly. In recent years, with a continuous widening trade gap, there are frequent trade frictions and disputes between the two countries, which can interfere with the bilateral trade development of the two countries. Meantime, it is noted that there is a large statistical trade discrepancies between China and US. For example, according to the statistics provided by China's Customs, the American trade deficit with China reached from US\$ 6.3 billion to US\$ 114.2 billion from 1993 to 2005, but according to the statistics provided by American Customs, the American trade deficit was from US\$ 22.8 billion to US\$ 201.6 billion from 1993 to 2005. This statistical trade discrepancy is so large that the problem of trade balance between China and US becomes more complicated.

According to the methodology of the balance of payments, a country's trade deficit must be equal to another country's trade surplus. Why there is a so big statistical trade discrepancy between China and US? What the deep causes of imbalance trade between China and US are? This paper tries to make a study on these two issues.

\section{Literature Review}

In recent years, with a rapid increase of China's foreign trade dependence and a further deterioration of trade friction between China and US, many Chinese scholars have published a lot of research articles on the issue of the trade balance between China and US. Theses articles cover the following aspects of the issue, namely, the analysis of the causes of the trade balance between China and US, the analysis of the statistical discrepancies of trade balance between China and US and relevant policies.

As to the causes of the problem of the trade balance between the two countries, many researchers think by common consent that different statistical techniques, the US trade protectionist policy, the adjustment of regional industry, structural adjustment and intra-company transactions are main causes of the problem of the trade balance. Zhang Hanlin (2003) [1] believes that the American national policies caused the huge amount of trade deficit in US. The empirical studies of Kang Meiling (2006) [2], Wang Xuefeng (2004) [3] have shown that the causes of the trade deficit in US are as follows: the imbalance between savings and investment in the macro-economic structures of China and US, the different statistical channels used by China-US, the transfer effect of the industry transfer in Asia and Pacific Rim that caused the American trade deficit with other countries transferred into China and the US export control systems etc. Chen Zaishi (2004) [4], based on the data of bilateral trade between China and US and Balance of Trade, studies the imbalance of trade between the two countries, and concludes that the underlying cause of the imbalance of trade of the two countries is that China's economy and the American economy are complements each of the other and the aggregate demand is over the aggregate supply in American economic structure. As to the statistical trade discrepancies, Song Yijun (2004) [5] concludes that the root cause of the big statis- 
tical trade discrepancy is the problem of standard of the trade partner's categories. Specifically, the factor of Hong Kong (HK) trade transfer, China's rapid development of processing trade and the American abuse of origin rule are the main causes. Cao Qian and He Jianming (2004) [6], Shen Guobing (2005) [7], Lau L. J. and Fung K. C. (2003) [8] et al. have made empirical studies on the statistical trade discrepancies between China and US. The findings of Shen Guobing's research indicate that the problem of the imbalance trade between China and US is beyond the trade scope of the two countries and becomes a problem of trade deficit transfer caused by FDI in China.

As to the relevant policies of trade balance between the two countries, Liu, Chunhong (2006) [9] suggests that China should adjust its economic development pattern and alter its trade policy. Foreign literature concludes that the statistical trade discrepancy made by US is not as big as it is. Chandong Huang and Simon Boadbent (1998) [10], Jialin Zhang (2000) [11], Fung K. C. and Lau L. J. (1998) [12], USCB (2004) [13], etc., all argue that the imbalance trade between China and US is not as big as that the US expects. Based on the previous literature, this paper re- thinks the China-US balance of trade. Renovations are as follows:

1) By eliminating the influence of statistical factor, it analyses the deeper causes of imbalance trade between the two countries.

2) By adjusting the data of trade from 1989 to 2005 reported by Chinese government and the US government, it tries to re-estimate the real imbalance of trade between the two countries. It then attempts to analyze the economic factors of imbalance of trade between China and US.

\section{The Adjustments of Trade Balance between China and US: 1989-2005}

It is known that there are trade statistical discrepancies in the imbalance of trade between China and US. We make a series of adjustments of Chinese official statistical data and US official statistical data so that we can obtain actual trade statistical discrepancies between the two countries. Table 1 shows China and US official trade statistical data.

Table 1. 1989-2005 China-US bilateral trade statistics (US\$ billion).

\begin{tabular}{|c|c|c|c|c|c|c|}
\hline \multirow{2}{*}{ Year } & \multicolumn{2}{|c|}{ US statistics } & \multicolumn{2}{|c|}{ China statistics } & \multirow{2}{*}{$\begin{array}{c}\text { China-US trade } \\
\text { balance (US statistics) }\end{array}$} & \multirow{2}{*}{$\begin{array}{l}\text { China-US trade } \\
\text { balance (China statistics) }\end{array}$} \\
\hline & $\begin{array}{l}\text { Export value } \\
\text { to China }\end{array}$ & $\begin{array}{l}\text { Import value } \\
\text { from China }\end{array}$ & $\begin{array}{l}\text { Import value } \\
\text { from US }\end{array}$ & $\begin{array}{l}\text { Export value } \\
\text { to US }\end{array}$ & & \\
\hline 1989 & 5.8 & 12 & 7.9 & 4.4 & -6.2 & 3.5 \\
\hline 1990 & 4.8 & 15.2 & 6.6 & 5.2 & -10.4 & 1.4 \\
\hline 1991 & 6.3 & 19 & 8 & 6.2 & -12.7 & 1.8 \\
\hline 1992 & 7.4 & 25.7 & 8.9 & 8.6 & -18.3 & 0.3 \\
\hline 1993 & 8.8 & 31.5 & 10.7 & 17 & -22.8 & -6.3 \\
\hline 1994 & 9.3 & 38.8 & 14 & 21.5 & -29.5 & -7.5 \\
\hline 1995 & 11.7 & 45.6 & 16.1 & 24.7 & -33.8 & -8.6 \\
\hline 1996 & 12 & 51.5 & 16.2 & 26.7 & -39.5 & -10.5 \\
\hline 1997 & 12.8 & 62.5 & 16.3 & 32.7 & -49.7 & -16.4 \\
\hline 1998 & 14.3 & 71.2 & 17 & 38 & -56.9 & -21 \\
\hline 1999 & 13.1 & 81.8 & 19.5 & 41.9 & -68.7 & -22.4 \\
\hline 2000 & 16.3 & 100.1 & 22.4 & 52.1 & -83.8 & -29.7 \\
\hline 2001 & 19.2 & 102.3 & 26.2 & 54.3 & -83 & -28.1 \\
\hline 2002 & 22.1 & 125.2 & 27.2 & 70 & -103.1 & -42.7 \\
\hline 2003 & 28.4 & 152.4 & 33.9 & 92.5 & -124 & -58.6 \\
\hline 2004 & 34.7 & 196.7 & 44.7 & 124.9 & -162 & -80.3 \\
\hline 2005 & 41.8 & 243.5 & 48.7 & 162.9 & -201.6 & -114.2 \\
\hline
\end{tabular}

Source: US Department of Commerce, China Customs. Note: “+” means US Surplus, “_” means US Deficit. Based on the figures in Table 1, we do the following adjustment estimates of China and US bilateral trade balances: 1989-2005. 
Based on the figures in Table 1, we do the following adjustment estimates of China and US bilateral trade balances: 1989-2005.

\subsection{Conversion of FAS into FOB and CIF into FOB}

We choose FOB as basic measurement of import and export data so that we can have the same basic measurement. FOB includes the costs of the merchandise, the transportation costs and the costs of loading the merchandise on the vessel in the country of origin, but the US uses FAS to calculate the statistics of exports, which is not similar to other countries'. The difference between FAS and FOB is the costs of loading the merchandise on the vessel. We add $1 \%$ to the value of exports under FAS term. As China uses FOB as basic measurement to record the export data, we do not make any adjustment, and we do not make any adjustment of the US Customs statistics of imports, which is basically the same as the FOB's. China uses CIF to re- cord the import data. Generally speaking, the estimates of value of CIF is about the value of FOB plus $10 \%$, so we deduct 1.1 from CIF value, then we can get the FOB value. The adjusted results are given in Table 2 .

The specific adjustment formulas are as follows:

US statistical data: Adjusted US import value from China $=$ US export value to China $\times 1.01$.

Adjusted US export value to China = US import value from China.

China statistical data: Adjusted China export value to US = China export value to US.

Adjusted China import value from US = China import value from US/1.1.

From Table 2, we can see that through the calculation of the conversion of FAS into FOB and CIF into FOB, the US trade deficit decreases, while China's trade surplus increases. On the whole, the statistical discrepancies are insignificant, which indicates that different methods of price calculation have little impact on the statistics of trade balance between China and US.

Table 2. FOB Converted statistics of China-US balance trade (US\$ billion).

\begin{tabular}{|c|c|c|c|c|c|c|}
\hline \multirow{2}{*}{ Year } & \multicolumn{2}{|c|}{ US statistics } & \multicolumn{2}{|c|}{ China statistics } & \multirow{2}{*}{$\begin{array}{l}\text { China-US trade } \\
\text { balance (US statistics) }\end{array}$} & \multirow{2}{*}{$\begin{array}{c}\text { China-US trade } \\
\text { balance (China statistics) }\end{array}$} \\
\hline & $\begin{array}{c}\text { Export value } \\
\text { to China }\end{array}$ & $\begin{array}{l}\text { Import value } \\
\text { from China }\end{array}$ & $\begin{array}{l}\text { Import value } \\
\text { from US }\end{array}$ & $\begin{array}{l}\text { Export value } \\
\text { to US }\end{array}$ & & \\
\hline 1989 & 5.9 & 12 & 7.2 & 4.4 & -6.1 & 2.8 \\
\hline 1990 & 4.8 & 15.2 & 6.0 & 5.2 & -10.4 & 0.8 \\
\hline 1991 & 6.4 & 19 & 7.3 & 6.2 & -12.6 & 1.1 \\
\hline 1992 & 7.5 & 25.7 & 8.1 & 8.6 & -18.2 & -0.5 \\
\hline 1993 & 8.9 & 31.5 & 9.7 & 17 & -22.6 & -7.3 \\
\hline 1994 & 9.4 & 38.8 & 12.7 & 21.5 & -29.4 & -8.8 \\
\hline 1995 & 11.8 & 45.6 & 14.6 & 24.7 & -33.8 & -10.1 \\
\hline 1996 & 12.1 & 51.5 & 14.7 & 26.7 & -39.4 & -12.0 \\
\hline 1997 & 12.9 & 62.5 & 14.8 & 32.7 & -49.6 & -17.9 \\
\hline 1998 & 14.4 & 71.2 & 15.5 & 38 & -56.8 & -22.5 \\
\hline 1999 & 13.2 & 81.8 & 17.7 & 41.9 & -68.6 & -24.2 \\
\hline 2000 & 16.5 & 100.1 & 20.4 & 52.1 & -83.6 & -31.7 \\
\hline 2001 & 19.4 & 102.3 & 23.8 & 54.3 & -82.9 & -30.5 \\
\hline 2002 & 22.3 & 125.2 & 24.7 & 70 & -102.9 & -45.3 \\
\hline 2003 & 28.7 & 152.4 & 30.8 & 92.5 & -123.7 & -61.7 \\
\hline 2004 & 35.0 & 196.7 & 40.6 & 124.9 & -161.7 & -84.3 \\
\hline 2005 & 42.2 & 243.5 & 44.3 & 162.9 & -201.3 & -118.6 \\
\hline
\end{tabular}

Source: The Author's Calculation and www. uschina. org/ public /wto/uscbc/balanceoftrade.html. Note: “+” means US Surplus, “-” means US Deficit. 


\subsection{The Adjustment of the Value of Hong Kong (HK) Transit Trade and Transit Added Value of Transit Trade}

The problem of transit trade causes the trade data of China and US complicated. It is uncertain that how much value of HK transit trade China's export data contain. In principle, China's import data contain the value of HK transit trade. Therefore, it is unnecessary for China to add American trade value of HK transit trade from US to the data of China's import from US. We believe that China's official export data show only direct export and we shall add the value of indirect export to US through HK transit trade to China's official export data. For US official data, similarly, the US official export data only contain direct export to China. We shall add the value of indirect export to China through HK transit trade to US official export data. For import data, we know that US Customs follows the rules of origin to record all the exports, including transit trade. So we need not add China's export to US through HK transit trade or other countries transit trade to US official import data. The HK official trade data from China's import through transit trade to US are HK DES (Delivered Ex Ship). The price of HK DES includes the costs, insurance and freight to bring the import goods from China to HK. Therefore, we shall divide it by 1.1 so that we can get the data of DES China import from China through HK transit trade. We may use the same method to treat the HK official data of import from US through transit to China. The value of transit trade accounts for a considerable proportion of China-US trade because when the goods are exported to HK, the middlemen put added value to the goods and then re-export. As this added-value occurs in HK, it causes the statistics of China-US trade more complicated. We should deduct this added-value in US-China trade data. The adjusted results are listed in Table 3.

The further adjustment formulas based on Table 2 are as follows:

US statistical data: Adjusted US export value to China = US export to China + US export to China through HK transit / [1.1 × $(1+$ transit added value rate $)]$.

Table 3. China-US trade statistics adjusted of transit-trade and transit-trade added-value (US\$ billion).

\begin{tabular}{|c|c|c|c|c|c|c|c|c|}
\hline Year & $\begin{array}{c}\text { US } \\
\text { statistics } \\
\text { export } \\
\text { (FOB) }\end{array}$ & $\begin{array}{l}\text { US FOB } \\
\text { through HK } \\
\text { transit to } \\
\text { China }\end{array}$ & $\begin{array}{c}\text { Transit } \\
\text { trade } \\
\text { added-value } \\
\text { rate }\end{array}$ & $\begin{array}{c}\text { Adjusted } \\
\text { US } \\
\text { export } \\
\text { statistics }\end{array}$ & $\begin{array}{c}\text { China } \\
\text { export to } \\
\text { US } \\
\text { (FOB) }\end{array}$ & $\begin{array}{l}\text { China } \\
\text { FOB through } \\
\text { HK transit } \\
\text { to US }\end{array}$ & $\begin{array}{c}\text { Transit } \\
\text { trade } \\
\text { added-value } \\
\text { rate }\end{array}$ & $\begin{array}{c}\text { Adjusted } \\
\text { China } \\
\text { export } \\
\text { statistics }\end{array}$ \\
\hline 1989 & 5.9 & 1.3 & $10.30 \%$ & 7.1 & 4.4 & 8.5 & $11.50 \%$ & 12.0 \\
\hline 1990 & 4.9 & 1.3 & $11.30 \%$ & 6.1 & 5.2 & 10.5 & $17.40 \%$ & 14.1 \\
\hline 1991 & 6.4 & 1.7 & $9.30 \%$ & 8.0 & 6.2 & 13.4 & $20.50 \%$ & 17.3 \\
\hline 1992 & 7.5 & 2.4 & $9.30 \%$ & 9.7 & 8.6 & 18.1 & $22.90 \%$ & 23.3 \\
\hline 1993 & 9.0 & 3.2 & $7.80 \%$ & 11.9 & 17.0 & 21.8 & $26.10 \%$ & 34.3 \\
\hline 1994 & 9.5 & 3.7 & $5.70 \%$ & 13.0 & 21.5 & 25.3 & $24.90 \%$ & 41.8 \\
\hline 1995 & 11.9 & 5.0 & $8.40 \%$ & 16.5 & 24.7 & 27.6 & $26.70 \%$ & 46.5 \\
\hline 1996 & 12.2 & 5.9 & $7.63 \%$ & 17.7 & 26.7 & 29.2 & $26.03 \%$ & 49.9 \\
\hline 1997 & 13.1 & 6.0 & $6.87 \%$ & 18.7 & 32.7 & 31.3 & $25.37 \%$ & 57.7 \\
\hline 1998 & 14.6 & 5.3 & $6.10 \%$ & 19.6 & 38.0 & 31.1 & $24.70 \%$ & 62.9 \\
\hline 1999 & 13.4 & 5.4 & $8.80 \%$ & 18.3 & 41.9 & 32.1 & $27.70 \%$ & 67.0 \\
\hline 2000 & 16.6 & 6.1 & $12.10 \%$ & 22.1 & 52.1 & 36.4 & $28.60 \%$ & 80.4 \\
\hline 2001 & 19.6 & 6.5 & $14.40 \%$ & 25.3 & 54.3 & 33.2 & $28.40 \%$ & 80.2 \\
\hline 2002 & 22.5 & 6.2 & $12.80 \%$ & 28.0 & 70.0 & 34.3 & $26.80 \%$ & 97.1 \\
\hline 2003 & 29.0 & 6.2 & $11.20 \%$ & 34.5 & 92.5 & 33.3 & $26.40 \%$ & 118.8 \\
\hline 2004 & 35.4 & 5.8 & $10.10 \%$ & 40.7 & 124.9 & 35.5 & $29.40 \%$ & 152.3 \\
\hline 2005 & 42.6 & 6.0 & $10.10 \%$ & 48.1 & 162.9 & 38.2 & $29.40 \%$ & 192.4 \\
\hline
\end{tabular}

Source: The Author’s Calculation. Note: “+” means US Surplus, “-” means US Deficit. 
Adjusted US import value from China = US import value from China.

China's statistical data: Adjusted China export value to US = China export to US + China export to US through HK transit / [1.1 × $(1+$ transit added value rate $)]$.

Adjusted China import value from US = China import value from US.

Based on the calculations of the conversion of FAS into FOB and CIF into FOB, and the calculations of the value of HK transit trade and transit added-value, we obtain the adjusted results in Table 4 .

From the above adjustment process, we may find an interesting phenomenon (see Figure 1).

From this figure, we can see that after we exclude the different price rules of FAS and CIF and impact of HK transit trade and transit added-value, the statistical discrepancies of trade balance between China and US increase gradually every year. In the next section, we will make a study on the statistical impact of the service trade on the trade balance between China and US.

\subsection{The Statistics Adjusted by Service Trade}

So far what we concentrate on is all the problem of balance of commodity trade between China and US. However, since US is a traditional country of net service export, and the service trade is becoming more and more important in recent years, we take the service trade into

Table 4. China-US trade statistics adjusted through FOB and transit trade added-value adjusted (US\$ billion).

\begin{tabular}{|c|c|c|c|c|c|c|}
\hline \multirow{2}{*}{ Year } & \multicolumn{2}{|c|}{ US statistics } & \multicolumn{2}{|c|}{ China statistics } & \multirow{2}{*}{$\begin{array}{c}\text { China-US trade } \\
\text { balance(US statistics) }\end{array}$} & \multirow{2}{*}{$\begin{array}{c}\text { China-US trade } \\
\text { balance(China statistics) }\end{array}$} \\
\hline & $\begin{array}{l}\text { Export Value } \\
\text { to China }\end{array}$ & $\begin{array}{l}\text { Import value } \\
\text { from China }\end{array}$ & $\begin{array}{l}\text { Import Value } \\
\text { from US }\end{array}$ & $\begin{array}{c}\text { Export Value } \\
\text { to US }\end{array}$ & & \\
\hline 1989 & 7.1 & 12 & 7.2 & 12.0 & -4.9 & -4.8 \\
\hline 1990 & 6.1 & 15.2 & 6.0 & 14.1 & -9.1 & -8.1 \\
\hline 1991 & 8.0 & 19 & 7.3 & 17.3 & -11.0 & -10.0 \\
\hline 1992 & 9.7 & 25.7 & 8.1 & 23.3 & -16.0 & -15.2 \\
\hline 1993 & 11.9 & 31.5 & 9.7 & 34.3 & -19.6 & -24.6 \\
\hline 1994 & 13.0 & 38.8 & 12.7 & 41.8 & -25.8 & -29.0 \\
\hline 1995 & 16.5 & 45.6 & 14.6 & 46.5 & -29.1 & -31.8 \\
\hline 1996 & 17.7 & 51.5 & 14.7 & 49.9 & -33.8 & -35.1 \\
\hline 1997 & 18.7 & 62.5 & 14.8 & 57.7 & -43.8 & -42.8 \\
\hline 1998 & 19.6 & 71.2 & 15.5 & 62.9 & -51.6 & -47.5 \\
\hline 1999 & 18.3 & 81.8 & 17.7 & 67.0 & -63.5 & -49.3 \\
\hline 2000 & 22.1 & 100.1 & 20.4 & 80.4 & -78.0 & -60.0 \\
\hline 2001 & 25.3 & 102.3 & 23.8 & 80.2 & -77.0 & -56.3 \\
\hline 2002 & 28.0 & 125.2 & 24.7 & 97.1 & -97.2 & -72.3 \\
\hline 2003 & 34.5 & 152.4 & 30.8 & 118.8 & -117.9 & -88.0 \\
\hline 2004 & 40.7 & 196.7 & 40.6 & 152.3 & -156.0 & -111.7 \\
\hline 2005 & 48.1 & 243.5 & 44.3 & 192.4 & -195.4 & -148.1 \\
\hline
\end{tabular}

Source: The Author’s Calculation. Note: “+” means US. Surplus, “-” means US Deficit. 


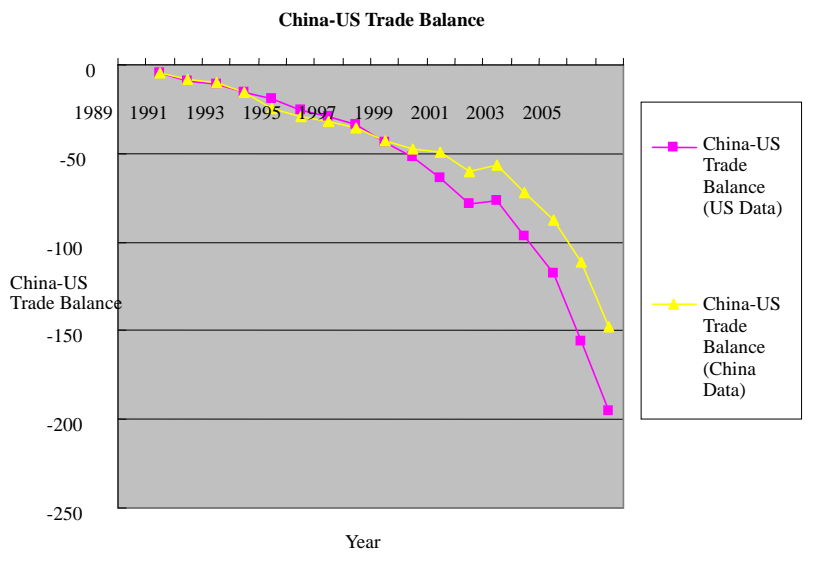

Figure 1. China-US trade statistical discrepancy. our consideration as the third adjustment. China's entry into WTO means that the service industries in China such as banking, insurance, and information will be opened further to the outside world. The adjusted estimates of balance of the bilateral trade are listed in Table 5 through the conversion of FAS into FOB and CIF into FOB, transit trade, transit added-value and private service trade. The private service includes advertisement, computer and data processing service, education, financial service (including banking and financial companies), professional service (including accounting and lawyer firms), management consulting, royalty, telecommunication, transportation, and tourism. Table 5 indicates US enjoys a steady service trade surplus with China.

Table 5. China-US trade statistics adjusted by service trade (US\$ billion).

\begin{tabular}{|c|c|c|c|c|c|c|}
\hline Year & $\begin{array}{c}\text { China-US trade } \\
\text { balance } \\
\text { (US statistics) }\end{array}$ & 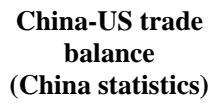 & $\begin{array}{l}\text { US service } \\
\text { export to } \\
\text { China }\end{array}$ & $\begin{array}{l}\text { US service } \\
\text { import from } \\
\text { China }\end{array}$ & $\begin{array}{c}\text { China-US } \\
\text { trade balance } \\
\text { (US statistics) }\end{array}$ & $\begin{array}{c}\text { China-US } \\
\text { trade balance } \\
\text { (China statistics) }\end{array}$ \\
\hline 1989 & -4.9 & -4.8 & - & - & -4.9 & -4.8 \\
\hline 1990 & -9.1 & -8.1 & - & - & -9.1 & -8.1 \\
\hline 1991 & -11.0 & -10.0 & - & - & -11.0 & -10.0 \\
\hline 1992 & -16.0 & -15.2 & 1.6 & 1.0 & -15.4 & -14.6 \\
\hline 1993 & -19.6 & -24.6 & 1.9 & 1.3 & -19.0 & -24.0 \\
\hline 1994 & -25.8 & -29.0 & 2.0 & 1.5 & -25.3 & -28.5 \\
\hline 1995 & -29.1 & -31.8 & 2.5 & 1.7 & -28.3 & -31.0 \\
\hline 1996 & -33.8 & -35.1 & 3.2 & 1.9 & -32.5 & -33.8 \\
\hline 1997 & -43.8 & -42.8 & 3.6 & 2.2 & -42.4 & -41.4 \\
\hline 1998 & -51.6 & -47.5 & 3.9 & 2.3 & -50.0 & -45.9 \\
\hline 1999 & -63.5 & -49.3 & 4.0 & 2.7 & -62.2 & -48.0 \\
\hline 2000 & -78.0 & -60.0 & 5.2 & 3.3 & -76.1 & -58.1 \\
\hline 2002 & -97.2 & -72.3 & 6.0 & 4.1 & -95.3 & -70.4 \\
\hline 2003 & -117.9 & -88.0 & 5.9 & 3.9 & -115.9 & -86.0 \\
\hline 2004 & -156.0 & -111.7 & 7.2 & 5.6 & -154.4 & -110.1 \\
\hline 2005 & -195.4 & -148.1 & 7.2 & 5.6 & -193.8 & -146.5 \\
\hline
\end{tabular}

Source: The Author’s Calculation. Note: “+” means US Surplus, “-” means US Deficit. 


\subsection{The Analysis of Adjusted Results}

Figure 2 is an original trade balance of China and US; Figure $\mathbf{3}$ is an adjusted trade balance of China and US.

Comparing these two figures, we find that the discrepancies of the trade balance between the two countries become smaller. For example, the unadjusted statistical discrepancies in 2005 were US\$ 87.4 billion, while the adjusted statistical discrepancies were US\$ 47.3 billion, which decreased by nearly $50 \%$. However, we note that there are a part of the discrepancies, which are not explained, and the discrepancies are increasing with years. We believe that the processing trade accounts for a big proportion of the discrepancies. In effect, since 1990s, one of important factors for China to increase export to US is the increasing exports of the processing trade. It is estimated that the exports of the processing trade to US account for approximately $50 \%$ - 70\% in the volume of export, and they are produced by most FDI enterprises from the USA and other countries toward China. These products of the processing trades depend mainly on their original sales channels through the transit channels such as HK to export to US. As these products made in China change their origins, when the US records their exports based on the rules of origin, China is the country of origin for these products. The exports of these products from those FDI enterprises become China's exports, which transfer from the above countries to China.

\section{The Analysis of Economic Factors in China-US's Trade Balance}

The economic factors in China-US's trade balance involve not only the imbalance of American macro-economy, the adjustment of industry structure, but also intra-industry trade, intra-company dealings, the growing multinational companies and e-commerce.

\subsection{The Factor of the Domestic Demand in US}

It is noted that US trade deficit with China is only a small proportion of the total US trade deficit, comparing with the big US trade deficit, which is running at approximately US\$ 800 billion annually (Pingfan Hong, 2006) [14], but the US trade deficit is a problem, which is the result of some structural differentials between the US economy and China's economy. For example, the US's saving rate in 2005 was only $-5 \%$, while China's saving rate was $46 \%$.

The chief reason why US's saving rate continuously maintains low is that the country's new economy bubble brought an unreasonable prosperity to stimulate the household consumption and firm investment, which result in the imbalance of macro-economy in US. The US trade deficit has filled a gap of its domestic demand and supply.

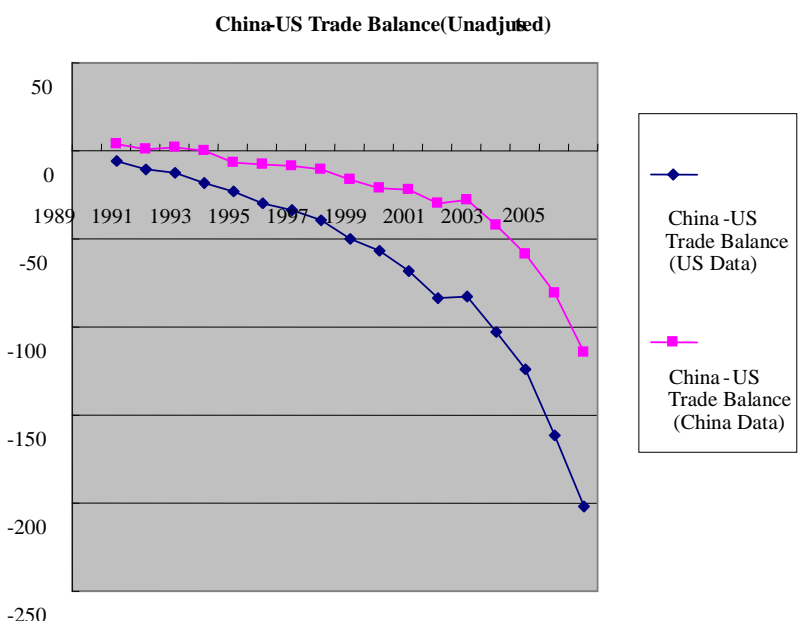

Figure 2. China-US trade balance (unadjusted statistics).

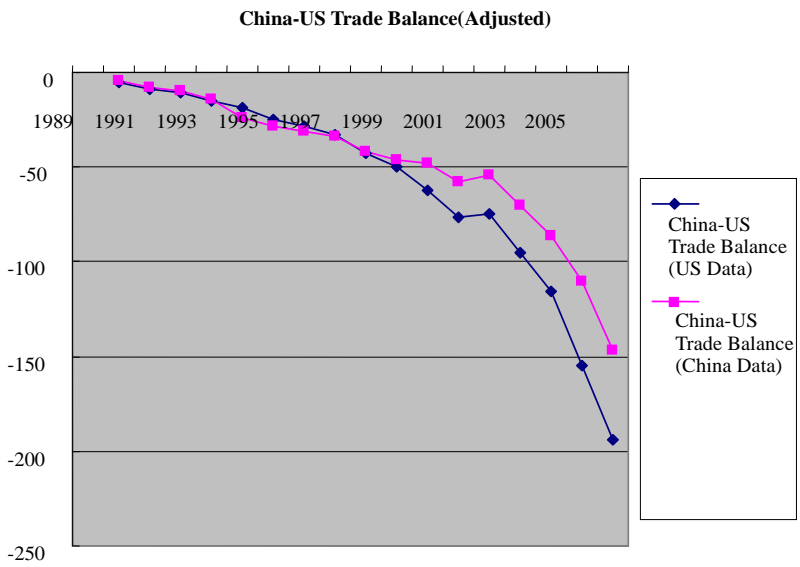

Figure 3. China-US trade balance (adjusted statistics).

Supposing US stops importing from China just because of its big trade deficit with China, the situation is that the US total trade deficit will not decrease, but it will have to increase imports from other countries. Consequently, its big trade deficit still remains unchanged, and moreover, its import cost will increase and its consumers' and manufacturers' burden will increase, for China's exports are very competitive with other countries'. If the US really wants to solve the problem of trade deficit, it has to attain a balance of its aggregate supply and its aggregate demand. So the problem of the imbalance of trade between China and US is not a mere problem of bilateral trade.

\subsection{The Factor of the Adjustment of US Industry Structure}

One of the reasons of US big trade deficit is dependent on the roles of its fundamental economy and institution. The adjustment of US industry structure mainly shows that as the rapid development of science and technology in the world results in the occurrence of the third large- scale of industry transfer in the development history of the world 
industry, the US multinational companies (MNC) take advantage of their multi-monopolistic advantage to invest heavily in developing countries. They transfer those labor-intensive industry, resource and energy-consuming industry and even heavy pollutant-industry and low addedvalue processing industry into developing countries, while they concentrate on developing high-tech industry and service industry.

China's trade surplus with US is a normal phenomenon that reflects the adjustment of US industry structure. On the one hand, China's export of labor-intensive products is beneficial to the adjustment of US industry structure because the US can transfer their labor-intensive industries into other countries. They can meet the domestic demand by Chinese imports.

On the other hand, in recent years, with the adjustment of US industry structure and China's deeper economic reform, the US MNC's investments in China are steadily increasing and become an important factor that deteriorate the imbalance trade of the two countries.

\subsection{The Factor of Intra-Industry Trade, MNC's Intra-Trade and E-Commerce}

The factor of intra-industry trade and MNC's intra-trade are also the main factors to explain why the imbalance trade of China and US sharply rises. With the industry adjustment in the world and development of the globalization of the economy, the boom in MNCs widens the imbalance trade of the two countries. The US MNCs gain more profit from their investment in China and occupy a larger share in the market.

The impact of e-commerce (EC) on the imbalance trade of China and US is becoming important as EC transactions are multiplying at an exponential rate, and the EC will continue to expand rapidly. It is hard to trace the volume of trade between the two countries because of uniqueness of the EC. Therefore, the statistics of the trade balance of China and US is not accurate, and the statistical discrepancies of the balance of trade between China and US are not as big as the US expects.

\section{Conclusion}

Based on the above analysis, it is concluded that the imbalance of China-US trade is not as big as it was reported by US. At present, the China-US trade surplus is an inter-complementary trade surplus, which is an inevitable result from different industry structures. Moreover, most FDI enterprises from the USA and other countries towards China contribute greatly to the expansion of processed trade export in China, whose exports constitute a large proportion of the imbalance of trade between China and US. So it is quite necessary for China to perfect its foreign investment policies, and to improve the structure of inviting foreign investment to lower the magnifying effect on the China-US trade surplus produced by FDI enterprises. On the other hand, the USA should also relax its export controls on certain high-tech products, which China could otherwise have imported, to narrow the bilateral trade gap.

\section{REFERENCES}

[1] H. L. Zhang, "US Is the Root of Big Imbalance of Trade between China and US," China Reform, No. 12, 2003, pp. 33-34.

[2] M. L. Kang, "The Analysis of Causes of the Imbalance Trade between China and US," World Economy Study, No. 4, 2006, pp. 4-9.

[3] X. F. Wang, "A Study on the Imbalance of Trade between China and US,” Modern Economy, No. 12, 2004, pp. 5759.

[4] Z. S. Chen, "A New Study on the Imbalance of Trade between China and US,” Market Weekly, No. 7, 2004, pp. 21-22.

[5] Y. J. Song, "The Causes of the Imbalance Trade between China and US and Future Countermeasures," Shanghai Economy Study, No. 5, 2004, pp. 45-49.

[6] Q. Cao and J. M. He, "How Big the Imbalance Trade between China and US: Empirical Study on 1993-2002," China Soft Science, No. 8, 2004, pp. 74-78.

[7] G. B. Shen, "The Trade Statistical Discrepancy and the Problem of Balance Trade between China and US," Economic Study, No. 6, 2005, pp. 82-92.

[8] K. C. Fung and L. J. Lau, “Adjusted Estimates of United States China Bilateral Trade Balances: 1995-2002,” Journal of Asian Economics, Vol. 14, No. 3, 2003, pp. 489-4 96. doi:10.1016/S1049-0078(03)00040-X

[9] C. H. Liu, "The Problem of China-US Trade and Countermeasures," Statistics and Decision, No. 4, 2006, pp. 140143.

[10] C. D. Huang and S. Boadbent, "Trade with China: Do the Figures Add up?” International Review of Applied Economics, Vol. 12, No. 1, 1998, pp. 107-127. doi:10.1080/026921719800000028

[11] J. L. Zhang, "US China Trade Issues after the WTO and the PNTR Deal: A Chinese Perspective,” Hoover Essays in Public Policy, No. 103, 2000, pp. 1-24.

[12] K. C. Fung and L. J. Lau, "The China-United States Bilateral Trade Balance: How Big Is It Really?” Pacific Economic Review, Vol. 3, No. 1, 1998, pp. 33-47. doi:10.1111/1468-0106.00040

[13] The US China Business Council (USCBC), "Understanding the US China Balance of Trade,” 2004. http://www.uschina.org.statistics2004balanceoftrade.html http://www.uschina.org/public/wto/uscbc/balanceoftrade. htm.

[14] P. F. Hong, "China’s Economic Prospects and Sino-US Economic Relations,” China \& World Economy, Vol. 14, No. 2, 2006, pp. 45-55. doi:10.1111/j.1749-124X.2006.00014.X 